\title{
On Value Orientation in China and the West as Reflected in Man Creation by Nuwa and by the God
}

\author{
Huan Yan1, Haiyan Huang2 \\ ${ }^{1}$ College of International Education, Zunyi Medical University, Zunyi, China \\ ${ }^{2}$ Wuhan East Lake Hi-Tech Development Zone Office, State Administration of Taxation, Wuhan, China \\ Email: 465090628@qq.com,122073734@qq.com
}

How to cite this paper: Yan, H., \& Huang, H. Y. (2018). On Value Orientation in China and the West as Reflected in Man Creation by Nuwa and by the God. Creative Education, 9, 2505-2515.

https://doi.org/10.4236/ce.2018.915189

Received: October 22, 2018

Accepted: November 16, 2018

Published: November 19, 2018

Copyright $\odot 2018$ by authors and Scientific Research Publishing Inc. This work is licensed under the Creative Commons Attribution International License (CC BY 4.0).

http://creativecommons.org/licenses/by/4.0/

\begin{abstract}
Value orientation refers to value tendency that people have when they take a certain action in a certain way on a certain occasion. It is an important part of culture. Studying value orientation in different cultures can help people understand the differences between cultures so as to facilitate the cross-cultural communication. Mythology is an important part of culture. Man Creation mythology is a category of mythology and it is about human beings' thinking and interpretation of their origin. Value orientation in different cultures may originate from the Man Creation mythology of the respective cultures. In this paper, a comparative study of the value orientation between China and the west is made through comparing Man Creation by Nuwa in China and Man Creation by the God in the west and with regards to the characteristics of Chinese and western value orientation shown respectively in the two Man Creation mythologies. The study in this paper indicates that the two Man Creation mythologies reflect the differences in value orientation between China and the West on behavioral thinking, marriage relation and man-god relation. On behavioral thinking, Man Creation by Nuwa reflects emotionalism in China and Man Creation by the God reflects intellectualism in the West; on marriage relation, Chinese marriage is based on breeding offspring and western marriage is based on people's emotional and physical needs; on man-god relation, it is praying for blessing and giving blessing in China, while it is showing repentance and accepting repentance in the West.
\end{abstract}

\section{Keywords}

Man Creation Mythology, Value Orientation, Culture 


\section{Introduction}

As globalization is intensifying today, the communication and blending of eastern and western civilizations become more frequent. Thus, it is even more important to make a comparative study of Chinese and western cultures. Value orientation, the principles of right and wrong that are accepted by an individual or a social group, is one of the most important contents of culture, and culture is always reflected in value orientation. So value orientation study is a good way to study culture. Every nation has its own mythology, which is the echo of a nation's ancient history and it truly shows the shambling gait and the spirit of the struggle between human and nature. Ever since it came into being, mythology is bound to unconsciously affect a nation's customs and habits, and subsequently to penetrate into the deepest soul of the nation in the following history, forming a value and the nation's spirit ( $\mathrm{Zhu}, 2010: \mathrm{p}$. 101). Myth, as a product of the human's collective unconsciousness, can arouse the most profound national memory and imagination. Over generations, human beings have tended to explain the world through myth and turned it into specific viewpoints of the world, based on which, certain modes of thinking have been formed. Mythology plays a far-reaching role of nurturing the character of a nation's spirit and cultural psychology of the people. Mythology is the spiritual source and an essential part of national culture and national culture spirit. Although mythology is the fictional story by people, not all fictions can become a mythology. Mythology about ancient times is the fruit of primitive culture, which is passed on by all the people in oral form. It is the dispensable reference when people study primitive culture and society (Xie, 1986: p. 10). Man Creation mythology is a kind of mythology. It conveys human's understanding of the origin of human beings, which reveals the value orientation of the people in the nation. In view of this, the two Man Creation mythologies, Man Creation by Nuwa in China and Man Creation by the God in the west, are compared and analyzed in this paper. The comparative study shall be made through comparing and analyzing the characteristics and differences of Chinese and western value orientation in terms of behavioral thinking, marriage relation and man-god relation, so as to prove that the two mythologies, Man Creation by Nuwa in China and Man Creation by the God in the west, reflect the differences in value orientations between China and the west on behavioral thinking, marriage relation and man-god relation.

\section{Chinese and Western Behavioral Thinking Reflected in Man Creation Mythology}

Two different types of cultures produce two different ways of thinking (Xie, 2003: p. 84). Thinking is formed by the brain processing and generalizing of the things in reality, which is presented by the form of implicit or explicit actions or verbal forms.

Human thinking is the function of brain when brain develops to the advanced stage under the affluence of the production practice and it is the product of the 
long-term development of human history. Behavioral thinking gradually evolved in the background of certain objective environment and historical-cultural environment. Different behavioral thinking reflects all the fields of knowledge in different nations. And the difference in the way of thinking is one of the important causes of culture difference. Differences exist in Chinese and western behavioral thinking and the origin of some can be found in Man Creation mythology.

\subsection{Behavioral Thinking Reflected in Man Creation by Nuwa}

In Man Creation by Nuwa, after the world was opened up, although there were already mountains and vegetation, insects and animals, fish and birds, yet no human beings were there and the world was still desolate and lonely. Walking on the desolate land, Nuwa felt quite lonely and she thought there would be vitality between heaven and earth if something was added to it.

It can be inferred from these descriptions that in the beginning Nuwa didn't want to create man and treat man as the highest beings between heaven and earth. It was because she felt quite lonely and she wanted to dispel this feeling of loneliness that she pinched soil and created man. This reflects that before acting, Chinese people's impetus is emotional experience, which is a kind of external action converted from the internal emotion. With this emotional experience, people realize their original purposes.

Emotionalism can denote an inclination, which relies on or place too much value on emotion, as opposed to resorting to reason when dealing with reality. Chinese people are inclined to turn to their inner emotion when they are dealing with something, which presents a kind of emotionalism. Traditional Chinese culture dominated by the pursuit of human values is to illustrate illustrious virtue, to renovate the people and to rest in the highest excellence. For Chinese people, goodness is the highest manifestation of life and is the foundation that determines man as man. The fundamental requirement of goodness is to maintain good collective interests and keep group harmony. The pursuit of goodness is the pursuit of value in one's life and also the basic requirements of life ( $\mathrm{Du} \&$ Yao, 2000: p. 79).

\subsection{Behavioral Thinking Reflected in Man Creation by the God}

In Man Creation by the God, within seven days the God created all things. In the former six days, the God created the heaven and earth, the mainland and sea, animals and plants, sun and moon. The God let them live by their own and have their breeding and reproduction. On the last day, the God created man molded on his own image and let man manage the world.

It can be inferred from these descriptions that the process of the God creating all things between heaven and earth in the previous six days and man on the last day was conducted after the God's rational thought. The God first created all things, the foundation of the world, and at last created man, the manager of the world and the head of all creatures. The God wants human beings to manage the 
world and maintain the order and stability of the world. The thinking of the God is rigorous and the world he created is a systematic unit. This reflects before acting, western people's impetus is rational consideration. It is a kind of behavioral thinking that put the systematic thinking into external action.

In the West, people's pursuit of values in life focuses on knowledge and truth. Socrates put that "Virtue is knowledge", and he thought that ethical behavior must be founded on knowledge and derived from knowledge. Knowledge comes before ethics and is higher than morality. Goodness comes from knowledge and evil comes out of ignorance. In Plato's mind, philosophers must first be a wise man.

\subsection{Characteristics and Differences of Chinese and Western Value Orientation of Behavioral Thinking}

In Man Creation by Nuwa, Nuwa felt quite lonely and in order to dispel this loneliness, she pinched soil and created man. While In Man Creation by the God, in the former six days, the God created the heaven and earth, the land and sea, animals and plants, sun and moon, and on the last day, the God created man molded on his own image and let man manage the world. People's social behavior is constrained and driven by a certain social values (Xu \& Mei, 2002: p. 44). From the above analysis, the implicit value orientation of behavioral thinking reflected in the two Man Creation mythologies can be found.

Nuwa made man because she felt very lonely and after she made lots of men, she became happy and pleased. The whole process is filled with her inner feelings. While in Man Creation by the God, there is no related description of the inner state of the God, either before or after creating man. The basic spirit of Chinese people in the moral behavior is featured by art, focusing on the inner experience and state. The basic spirit of the western culture is of reason and science, and this spirit is also reflected in social norm system and restraint mechanism.

Chinese people's emotionalism, which is reflected as Nuwa's emotional need of creating man in the Chinese Man Creation mythology, can enhance the cohesion of interpersonal relationship, which can create a warm atmosphere, meet people's emotional needs, promote interpersonal harmony and social stability and develop a custom of mutual care and mutual help. However, it can also lead people to violate the nation's laws and principles because of the emotionalism and it can be the hotbed of nepotism and partisanship (Wu, 2007: p. 186). Moreover, it may prevent people's pursuing and concerning of knowledge, which objectively impedes the formation and development of science.

The intellectualism in the West, which is reflected as the God's logical thinking of creating man in the Western Man Creation mythology, emphasizes the consistency of knowledge and morality, especially the exploration of the natural science, which has fostered the intellectualism attitude in the West and the foundation of the rational thinking and scientific system. Thus, it promotes the 
growth of western scientific spirit and the rapid development of natural science. However, because intellectualism emphasizes too much on the value of knowledge, west nations develop a traditional orientation that pays too much attention to knowledge and less to morality. Thus, it is likely to form a kind of moral nihilism in the West. In addition, because intellectualism neglects emotion, it leads to the weakening of people's affection. With the development of market economy and the process of industrialization and the acceleration of urbanization, the interpersonal emotion bond gradually becomes slack, which intensifies the nervy interpersonal relation and results in people' frequent psychology illness, family crisis and turbulence of society.

From the above analysis, it can be summed up that the value orientation of Chinese and western behavioral thinking presents different characteristics, and there is great difference between them and each with advantages and disadvantages. When dealing with reality and making decisions, Chinese people are inclined to comply with their inner emotion, and their original motivations come from the satisfaction of their inner world; while people in the west tend to make rational thinking and analysis, and they prefer a scientific way of discussion.

\section{Chinese and Western Marriage Relation Reflected in Man Creation Mythology}

Marriage is a social union or legal contract between people that may create kinship. It is an institution in which interpersonal relationships, usually intimate and sexual, are acknowledged in a variety of ways, depending on the culture or subculture in which it is found. In all the nations, marriage relation contains three elements, sex, marriage and reproduction; China and the West also have these elements. But in these three elements, about which is considered the basic and decisive one, China and the West is not the same (Liu, 2002: p. 127). The source of the difference between them can be found in the two Man Creation mythologies.

\subsection{Marriage Relation Reflected in Man Creation by Nuwa}

In Man Creation by Nuwa, it seemed that Nuwa could stop working when she made a lot of men by pinching clay. But like other animals, man dies. Nuwa thought about the way to let human beings exist all the time in the world, because it was too troublesome and laborious to make man without a stop. Then she took men and women together, and let them have their own offspring and take the responsibility of bringing up children. Thus, in this way, generation by generation, there are more and more people in the world. Nuwa established the original marriage in China.

From these descriptions, it can be seen that China's marriage is characterized as: the original purpose of Chinese marriage is to keep the continual existence of human beings in the world, but not to meet the emotional or physical needs of men and women. China's marriage is based on family and maintaining family, 
which means it neglects sex, the emotional and physical needs of human.

\subsection{Marriage Relation Reflected in Man Creation by the God}

In Man Creation by the God, after blowing life breath into Adam, God created man from clay. Because Adam was lonely, God decided to make him a spouse. When Adam was sleeping, God took out of his Rib and created Eve. When he woke up, Adam saw Eve and he said "This is now bone of my bones, flesh of my flesh, she shall be called woman." So they went to live together.

The descriptions in Genesis state that the reason why the God made a companion for Adam: because God thought Adam must be quite lonely on his own and the feeling of loneliness is a normal human emotion. Adam was happy to see Eve and they two lived together happily, which can prove that God's decision is wise and right. It can be seen that western marriage is based on personal and physical emotion needs. In the West, the starting point of marriage is emotional or physical needs between men and women, but not breeding offspring or maintaining family.

\subsection{Characteristics and Differences of Chinese and Western Value Orientation of Marriage Relation}

In Man Creation by Nuwa, to let human beings exist all the time in the world, Nuwa took men and women together, and let them have their own offspring and take the responsibility of bringing up children. However, in Man Creation by the God, God made Adam a spouse so as to stop him from feeling lonely. And Adam lived happily with Eve. From the above analysis, the implicit value orientation of marriage relation reflected in the two Man Creation mythologies can be found out.

Chinese marriage relation is based on breeding offspring the first, marriage the second and physical need the last. In the West, the order is reverse: the bases of the western marriage relation are in the order of physical need, marriage and breeding offspring (Liu, 2002: p. 128).

It is a deep national tradition to treat sex merely as a way of reproduction and use reproduction to negate sex (Zhang, 1990: p. 66). What is reflected in the Chinese Man Creation mythology is that Nuwa put men and women together and let them breed offspring. The combination made by Nuwa is to maintain the existence of human in the world. Therefore, in China, it poses no threat to marriage if there is no love, but if a wife can't bear a baby, the marriage will have no roots, which is very dangerous for marriage. Chinese marriage is based on breeding offspring and maintaining family, therefore such a marriage is relatively stable. As Chinese marriage is on the reproduction basis, relatively speaking, sex is in a dispensable place. The meaning of marriage in Chinese culture is mainly understood as an extension of family and the blood of clan, so marriage is not treated as a personal fair, instead it is treated as a family matter, which in turn increases the stability of Chinese marriage. 
Among all kinds of love, sex is the one which is the most enthusiastic, confusing and stability-lacking (Wei, 1988: p. 250). What is reflected in the western Man Creation mythology is that the God's original purpose is making Adam not feel lonely. Living with Eve, Adam felt quite happy because his emotional and physical needs were met. Based on sex, the western marriage always includes a kind of hidden crisis. Meanwhile, the western marriage is based on sex, and sex is purely human nature, so for westerners, in principle, marriage is firstly a fair of their own, but not of others. Therefore, westerners tend to choose their own spouses independently, and they can't tolerate other people, including their parents, to make the choices for them. For westerners, marriage is personal and rooted in sex, and as a result, the western marriage is unstable and likely to change. Besides, the human nature, "grass is always greener on the other side of the fence", strengthens the instability. Therefore, relatively speaking, western marriage lacks stability.

Westerners view marriage differently from Chinese people. Because they believe that marriage is purely a private matter and no one else can interfere in it; and also they think that marriage is not an issue concerning morality. This is reflected as the God made Adam a spouse by taking out a rib from Adam, which showed the intimate relation between Adam and Eve. In the West, one has the right to choose a person that one loves most and then lives together with him or her. If they find their marriage is a mistake, they will make a second choice and find another one who is more suitable. If one in the couple falls in love with a third people, he or she will not be condemned. In their view, it is cruel to force two people live together without love. China's traditional idea of marriage is that marriage should be a harmonious union forever and the couple can never change. The problem is that in real life, there are various problems that may make the family crack. Small problems can be mediated, but a big problem can be hard to solve.

From the above analysis, it can be summed up that the value orientation of Chinese and western marriage relations presents different characteristics, and there is great difference between them and each with advantages and disadvantages. Chinese marriage is based on breeding offspring and it is very stable and with a relative low divorce rate. While western marriage is on the basis of emotional and physical needs, which is more suitable for human beings' sentiment and affection. But it is not stable as Chinese marriage, so the divorce rate is relatively high in western countries.

\section{Chinese and Western Man-God Relation Reflected in Man Creation Mythology}

Religion, a cultural category, can reflect value orientation of different nations. As for what the cultural foundation of religion is and how the initial momentum of religion is, it will eventually come to man-god relation. Man-god relation is an essential element of religion culture which plays an important role in forming 
the value orientation and its origin can be found in the two Man Creation mythologies.

\subsection{Man-God Relation Reflected in Man Creation by Nuwa}

In Man Creation by Nuwa, in order to maintain human's existence in the world, Nuwa imitated the reproduction method adopted by all the things in the world and let men and women breed offspring. She established the regulation for human combination. Because they are god-like creatures, human beings must be different from other animals. Here, Nuwa made great contributions to the tradition of reproduction and marriage of human beings, so she is respected and admired by the descendants. People sacrifice this god with grand ceremonies, building alters in the country and setting up temples. And people also offer her with "Tao Lao" custom. People pray to her for a happy marriage and flourishing descendants.

As it is reflected in the Chinese Man Creation mythology, the relation between man and god is a relation of praying for blessing and giving blessing. Man prays to god and prays for god's blessing, removal of disasters and difficulties, a splendid harvest and a happy family. And god plays the role of blessing the masses. The essence in Chinese belief of fate is a relation which is an expression of belief and power, and an interest relation of China's social network characteristics, a secular religion based on practical reason. None of them is a mere religion or a religious belief, that's why people get confused about what Chinese people's belief really is.

\subsection{Man-God Relation Reflected in Man Creation by the God}

In Man Creation by the God, after Adam and Eve were created by the God, they two lived in the Garden of Eden. They were attempted by the snake and they ate the fruit of wisdom, committing the first crime in human history, which is known as the "original sin". After they committed the crime, they were driven out of the garden by the God and they went to the world to undergo the hardships of life. In the Christian doctrines, the biggest or even the whole mission in one's life is in atonement for their ancestors' mistakes and guilt.

It can be inferred from the mythology that the western man-god relation is showing repentance and accepting repentance. Men show repentance to the God, and the God accepts their repentance and rescues their soul. The western man-god relation is a monotheistic religion which is centered Christianity. It's an absolute relation and is based on the characteristic of absolute obedience. This relation between God and man surpasses any secular world relations and it forms three spirit requirements. First, the God is absolutely unique; secondly, one should have universal love for colleagues and treat the God as father; lastly, one has to transcending worldly fairs and let the law deal with right things. Christianity is not a legal part of itself. To this end, Christian belief overthrows the various gods in states and families, and breaks the families and the class sys- 
tems, establishing monotheism which has transcendence, and exclusiveness ( $\mathrm{Li}$, 2006: p. 16).

\subsection{Characteristics and Differences of Chinese and Western Value Orientation of Man-God Relation}

In Man Creation by Nuwa, Nuwa made great contributions to the tradition of reproduction and marriage of human beings and she is greatly respected and admired by the descendants. People pray for a happy marriage and flourishing descendants from Nuwa. While in Man Creation by the God, having committed the "original sin", Adam and Eve were driven out of the garden by the God and they went to the world to undergo the hardships of life. From then on, westerners have to atone for their ancestors' mistakes and guilt to the God.

When Chinese people believe in gods, they pay more attention to the practical use in daily life. And they adopt an attitude that they turn to gods only when it is necessary. They don't need a certain god to rescue their soul. While in the western Christian belief, they should first admit their guilt and they believe that only the God can rescue their soul. In their eyes, the God is absolutely correct, all-powerful, omniscience and omnipresent (Zhu, 2002: p. 166).

Chinese proverb, “Don't have your cloak made when it begins to rain", vividly expresses Chinese people's religion outlook and the typical summary of man-god relation. This is reflected in the Chinese Man Creation mythology as that people worshiped Nuwa after she established marriage and people thought that she had a certain power of making human beings blessed with a lot of children. When it comes to a certain time, people pray for something from god. On the relation between man and god, in western culture, the God is higher than man and man can only express awe to the God, which is reflected as the God wanted Adam and Eve to obey the rule he had set. After they violated his rule, the God punished them. In Chinese culture, the relation between man and god is equal. Man doesn't have to express awe to god and also there is no need to do so (Chen, 2003: p. 134). Generally, Chinese people hold a turning-away attitude to gods, because Chinese people believe in many gods and they would not feel guilty if they don't worship a certain god. In the practical life of the West, people own everything to the God, and associate everything they have to the God. They have a strong sense of guilty which is caused by not worshiping the God.

From the above analysis, it can be summed up that the value orientation of Chinese and western man-god relation present different characteristics, and there is great difference between them. Chinese man-god relation is a relation that man prays for blessing and god bestows blessing, while western man-god relation is a relation that man shows repentance and the God accepts repentance. In daily life, Chinese people are inclined not to pray for blessing when there is no practical need, and their praying motivations come from the practical needs or certain purposes; while the people in the West tend to show repentance all the time whether there is guilt or not. 


\section{Conclusion}

In this paper, the two Man Creation mythologies, Man Creation by Nuwa in China and Man Creation by the God in the West, have been compared. And respectively, the implicit Chinese value orientation and western value orientation in the two Man Creation mythologies have been studied. The characteristics and differences of Chinese and western value orientation have been analyzed from the three aspects: behavioral thinking, marriage relation and man-god relation. In terms of behavioral thinking, Man Creation by Nuwa reflects that Chinese people are emotionalists. When dealing with reality and making decisions, Chinese people are inclined to comply with their inner emotion, and their original motivations come from the satisfaction of their inner world. Man Creation by the God reflects that people in the West are intellectualists. When dealing with reality and making decisions, western people tend to make rational thinking and analysis, and they prefer a scientific way of discussion. In terms of marriage relation, Man Creation by Nuwa reflects that Chinese marriage is based on breeding offspring and is relatively stable; while Man Creation by the God reflects that western marriage is on the basis of emotional and physical needs, which is relatively instable. In terms of man-god relation, Man Creation by Nuwa reflects that Chinese man-god relation is praying for blessing and giving blessing; while Man Creation by the God reflects that western man-god relation is showing repentance and accepting repentance. The study and analysis of the two Man Creation mythologies can help find the origin of Chinese value orientation and western value orientation. It is concluded from the comparative study in this paper that there exist the differences in value orientation between China and the West on behavioral thinking, marriage relation and man-god relation, and they can be reflected in the two Man Creation mythologies: Man Creation by Nuwa and Man Creation by the God.

\section{Project}

Guizhou provincial foreign students brand courses (2016JWP-4).

\section{Funding}

This study is supported by the master's research start-up fund of Zunyi Medical University.

\section{Conflicts of Interest}

The authors declare no conflicts of interest regarding the publication of this paper.

\section{References}

Chen, L. (2003). Human and God: The Contradiction and Connection between Chinese and Western Cultures. Jiangsu Social Science, No. 4.

Du, Y. X., \& Yao, K. (2000). A Comparison of Traditional Chinese Values. Journal of 
He'Nan Technical College of Mechanical and Electrical Engineering, No. 9.

Li, X. P. (2006). Belief Revolution and Power Order. Shanghai: Shanghai People's Publishing House.

Liu, C. H. (2002). Culture and Personality: A Comparison of Cultural Differences between China and the West. Hefei: China Science and Technology Press.

Wei, Z. T. (1988). China's Wisdom. Changchun: Jilin Wenshi Publishing House.

Wu, C. X. (2007). Chinese Ethical Spirit. Guangzhou: Guangdong People’s Publishing House.

Xie, Y. P. (2003). Cultural Differences and Thinking Expressions between China and the West. Journal of Tianjin Adult Higher Learning, No. 4.

Xie, X. J. (1986). Myth and National Spirit. Jinan: Shandong Literature and Art Publishing House.

$\mathrm{Xu}$, G., \& Mei, L. (2002). On the Differences and Expressions of Chinese and Western Values. Journal of Yuzhou University (Social Sciences Edition, Bimonthly), No. 12.

Zhang, M. Y. (1990). Yellow Civilization. Shanghai: Shanghai Literature and Art Publishing House.

Zhu, O. (2010). The Influence of Chinese and Western Mythology on Chinese and Western Cultures. Journal of Xinxiang University (Social Science Edition), No. 8.

Zhu, Y. T. (2002). American Values: An Exploration of a Chinese Scholar. Beijing: Foreign Language Teaching and Research Press. 